\title{
EFFECTIVE MODEL FOR ANALYSIS OF WOOD-FRAMED TIMBER STRUCTURES
}

\begin{abstract}
J. MALESZA ${ }^{1}$
This paper presents new procedure modeling based on finite element method analysis of wood-framed timber structures. The fasteners linking boards of sheathing with the timber frame both modeled applying shell finite element, with individual material parameters, remain the main objective of this manuscript. Material parameters are obtained from experimental tests and numerical identification. The main objective of the paper is the elaboration of the numerical model with high precision of mapping, and, at the same time, diminishing the number of the unknown simplifying the process of the modeling of timber structures. The new presented method leads to a simplification of analysis of multistory wood-framed multifamily building structures.
\end{abstract}

Keywords: wood-framed buildings, numerical analysis, orthotropic material

\section{INTRODUCTION}

Wood-framed buildings represent a dominant branch of the building industry in the frame of residential construction. It has been underlined for four decades how low the energy consumption process of building elements composing in the plant is, as well as how short the time of realization is in the industrialization of construction operations. Most of light wood-framed buildings are constructed in the prefabricated systems.

1. PhD, Bialystok University of Technology, Faculty of Civil and Environmental Engineering, ul.Wiejska 45A, 15-351 Bialystok, Poland, e-mail: j.malesza@pb.edu.pl 
Construction technology consists of several stages of realization including displacements and lifting in the prefabricated plant, transport to the construction site, and finally assembly on site. The analytical models are focusing on the required load combinations and analysis appearing within the process of exploitation, and very often there are adoptions of a simplified form.

Due to recognizing the spatial, three-dimensional structure and behavior of the wall, floor diaphragms, and the whole building structure; their multi-layered combined structure shall be taken into account in the process of analysis.

Particularly difficult is precise formulation of connections between the timber frame and the boards of sheathing, inducing a large number of unknowns in the numerical analysis, and therefore the process of modeling becomes complicated. The three-dimensional wood-framed structure with a new model of fastener linking sheathing to framing is proposed in this paper. This new model of link in timber structure rationalizes to an accepted size volume of computational tasks moderating the precision of analysis.

\section{FORMERLY ELABORATED ANALYTIC MODELS IN WOOD-FRAMED STRUCTURES}

Analytical descriptions of wood-framed building structures with sheathing has been widely elaborated on since the seventies of the last century. Most of the proposed method of modeling is focused on the wall analysis due to detecting static and dynamic behavior and displacements of the diaphragm in its plane. There are recognized models regarding of mapping accuracy of construction details.

In the beam model $[1,2,3,4]$ frame elements of the timber structure are described as applying beam elements, while sheathing boards are represented by an adopted diagonal spring. The frame scheme of the structure is obtained in a result where triangle-creating beam elements are joined in nodes modeled applying non-dimensional spring elements of adequate stiffness.

In $[5,6,7]$ diaphragms of wood-framed structures with sheathing are modeled in the form of plane models applying the finite element method with beam and shell plane elements.

In the three-dimensional model [8] all diaphragm building elements are represented applying shell finite elements describing the timber-framed structure and sheathing. These shell elements were proposed and described applying orthotropic material parameters. The fasteners linking frame to 
sheathing were described adopting beam finite elements of isoparametric characteristics obtained from experimental tests of timber-to-sheathing board connections implemented in the FE- analysis.

Despite the significant number of proposed models, it still seems to be imperative to elaborate on a model easy in use, securing consistency of theoretic parameters obtained from the experiment at all stages of analysis; in the process of structure exploitation, transport, and assembly.

\section{NEW ANALYTICAL MODEL PROPOSAL}

A new three-dimensional (3D) model is proposed where all composing building large panel of the wood-framed structures with sheathing are both reducing the number of unknowns in the task and diminishing the size of the analytical problem. A new description of fastener linking sheathing with framing is proposed in the form of shell elements. The aim of introducing a new fastener model is its application in solutions of large tasks through a reduction of unknowns and a reduction of time for modeling in FE-analysis. These goals can be achieved through employment of wood-framed diaphragm shell elements of relatively big dimensions, condensed at the edges and corners of structures, linking frame to sheathing. The idea of this new model is shown in Figure 1a and the proposed model has been compared to the beam model presented in Figure $1 \mathrm{~b}$.
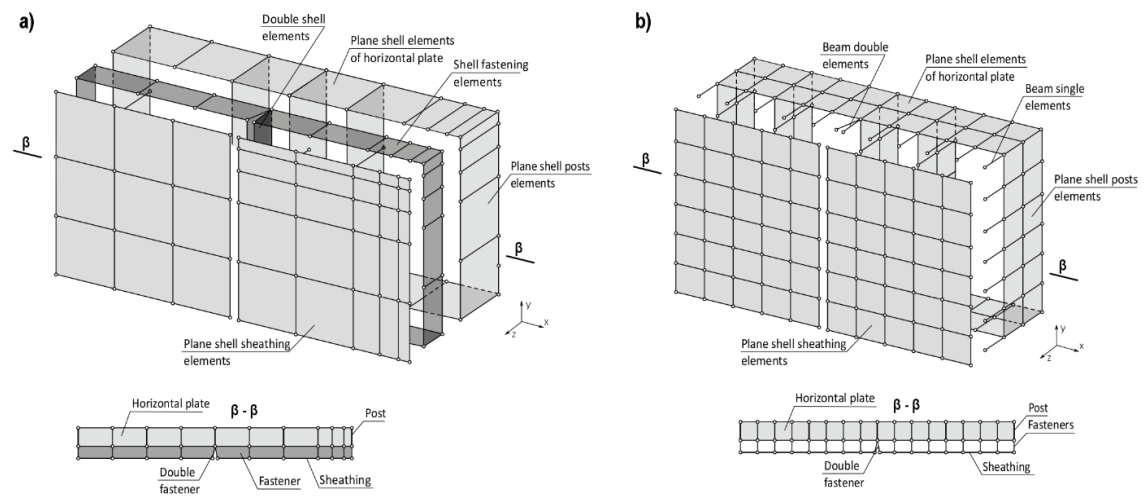

Fig. 1. Theoretical models used in analysis: a) proposed new model with application of shell elements with condensed discretization mesh at the edges and in the corners, b) former model with beam finite elements linking sheathing to framing of uniform spacing 
This model allows us to group fasteners in one larger element, condensing the discretization mesh in the region of extreme or concentrated stressing. The linking fasteners are described applying shell elements similar in form to those describing framing and sheathing. For realization of this task it is required to determine adequate material and geometry parameters, and for fasteners these parameters arise from common work of linking metal staples, timber framing, and wood-derivative sheathing board.

In the shell elements based on the Reissner-Mindlin theory, the orthotropic material matrix is a function of six variables and has the form (1.1):

$$
S=\left[\begin{array}{ccccc}
S_{11} & S_{12} & 0 & 0 & 0 \\
S_{21} & S_{22} & 0 & 0 & 0 \\
0 & 0 & S_{44} & 0 & 0 \\
0 & 0 & 0 & S_{55} & 0 \\
0 & 0 & 0 & 0 & S_{66}
\end{array}\right]
$$

where:

$S_{11}=\frac{1}{E_{1}}, S_{22}=\frac{1}{E_{2}}, S_{44}=\frac{1}{2 \cdot G_{12}}, S_{55}=\frac{1}{2 \cdot G_{28}}, S_{66}=\frac{1}{2 \cdot G_{31}}, S_{12}=-\frac{v_{21}}{E_{2}}, S_{21}=-\frac{v_{12}}{E_{1}}$, and $\mathrm{E}_{1} \mathrm{i} \mathrm{E}_{2}$ are modules of longitudinal elasticity along the material axes, $\mathrm{G}_{12}$ is the modulus of transverse elasticity for the plane state of element, $\mathrm{G}_{23}$ and $\mathrm{G}_{31}$ are the shear modules in the normal planes and $\mathrm{v}_{21}$ is the Poisson's ratio in the element plane. The system of coordinates describing timber frame structures and boards of sheathing is shown in Figure 2.
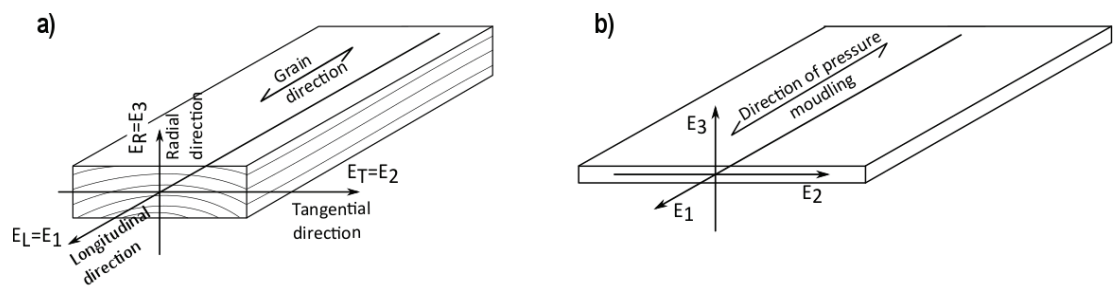

Fig.2 . Coordinates system of material axes in elements: a) timber framing, b) sheathing boards

Timber and OSB board parameters were obtained from tests of materials and they are to be used in direct application. The main problem refers to the evaluation of parameters of fasteners linking sheathing to framing. 
Two stages are recognized in the analysis. At first, linking staples parameters were described in the form of isotropic beam elements spaced on $50 \mathrm{~mm}$ along the timber frame element (posts or horizontal plates). Then, parameters of staples were adopted in analysis in the form of orthotropic shell elements. In addition, timber frame elements and sheathing are modeled applying shell elements. It is indispensable to evaluate values of $\mathrm{E}$ and $\mathrm{v}$ for linking beam elements and then $\mathrm{E}_{1}, \mathrm{E}_{2}, \mathrm{G}_{12}, \mathrm{G}_{23}, \mathrm{G}_{31}$, $\mathrm{v}_{21}$ for required shell elements.

\section{ELEMENT PARAMETERS COMPOSING THE WALL DIAPHRAGMS}

\subsection{TIMBER FRAMING AND SHEATHING BOARDS}

Material characteristics of posts and horizontal elements composing the wall diaphragms were obtained from experimental tests of samples cut out from spruce wood used for timber framing and sheathing boards OSB 3 thickness of $12 \mathrm{~mm}$. Obtained parameters are set in Table 1 .

Table 1. Material strength characteristics of spruce wood and OSB sheathing boards.

\begin{tabular}{|l|l|l|l|}
\hline \multicolumn{1}{|c|}{ Material } & \multicolumn{1}{|c|}{ Module of elasticity } & \multicolumn{1}{c|}{ Module of shear elasticity } & \multicolumn{1}{c|}{$v$ ratio } \\
\hline Wood & $\begin{array}{l}E_{1}=E_{L}=12000 \mathrm{MPa} \\
E_{2}=E_{T}=800 \mathrm{MPa}\end{array}$ & $\begin{array}{l}G_{12}=G_{L T}=670 \mathrm{MPa} \\
G_{31}=G_{L R}=586 \mathrm{MPa} \\
G_{23}=G_{R T}=34 \mathrm{MPa}\end{array}$ & $v_{21}=v_{L T}=0.280$ \\
\hline $\begin{array}{l}\text { OSB 3 sheathing } \\
\text { board }\end{array}$ & $\begin{array}{l}E_{1}=3703 \mathrm{MPa} \\
E_{2}=3260 \mathrm{MPa}\end{array}$ & $\begin{array}{l}G_{12}=1178 \mathrm{MPa} \\
G_{31}=560 \mathrm{MPa} \\
G_{23}=560 \mathrm{MPa}\end{array}$ & $v_{21}=0.242$ \\
\hline
\end{tabular}

\subsection{FASTENERS LINKING SHEATHING TO FRAMING}

\subsubsection{EVALUATION OF MATERIAL PARAMETERS FOR STAPLE CONSIDERED}

\section{AS THE BEAM FINITE ELEMENT}

Material characteristics of connections cannot be directly read from the experimental tests. Experimental tests of joints give information on the deformability of joints, hence its relation in the formula $\mathrm{C}=\mathrm{P} / \delta$ between shear load $P$ and slip $\delta$ in joints. The modulus of deformability represents steel fastener interaction and embedded materials where staples are sinking in. Evaluation of $\mathrm{E}$ and $\mathrm{G}$ module and $v$ ratio is conducted in numerical identification with determined deformability of joint. 
Wall sheathing is linked to framing using A38 staples of fastener arms $1.60 \times 1.30 \mathrm{~mm}$ in cross-section and arms in length of $37 \mathrm{~mm}$. Fasteners (staples) are placed at an angle of $45^{\circ}$ to the grain direction (along the longitudinal axis of timber framing - Figure 3a). Two arms of fastening staples are working in joints, and their cross-section moment of inertia according to Figure $3 \mathrm{~b}$ is equal: $\mathrm{J}_{\mathrm{x} 1}=\mathrm{J}_{\mathrm{y} 1}=51,697 \mathrm{~mm}^{4}$.

a)

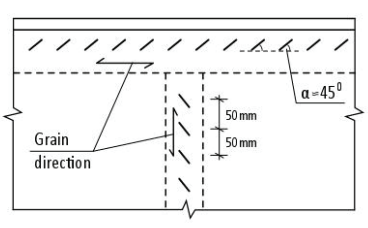

b)

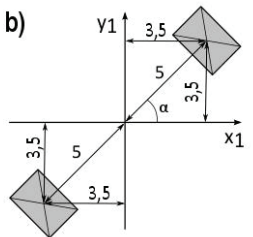

c)

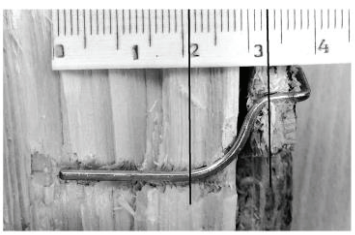

Fig. 3. a) Staples arrangement in joint, b) geometry of two arms of staple, c) fastener mode of failure

An adequate equivalent diameter of two arms of the cross-section area corresponds to a single rounded section of fastener $5.7 \mathrm{~mm}$ in diameter.

Within the tests (fig. 4) of connection displacements in joints in the elastic phase of loading exhibits slip equal $0.4 \mathrm{~mm}$, perpendicular to grain direction and adequately $0.3 \mathrm{~mm}$ in the direction parallel to the grain. Corresponding loads applied in the tests to joints are $277.5 \mathrm{~N}$ and $158.04 \mathrm{~N}$. Deformability modulus computed from formula $C=\frac{P}{\delta}$ are, $C_{p e r p}=\frac{277.5}{0,4}=693.75 \frac{\mathrm{N}}{\mathrm{mm}}$, $C_{\text {paralel }}=\frac{158.04}{0,3}=526.795 \frac{\mathrm{N}}{\mathrm{mm}}$. The average modulus of deformability value for both directions is $C=610.27 \frac{\mathrm{N}}{\mathrm{mm}}$.

Deformability modulus of staple fastener in the light of Standard PN-EN1995-1-1:2010 is equal $K_{s \theta r}=600.81 \frac{\mathrm{N}}{\mathrm{mm}}$ and it is adopted in the task.

Fastener required material parameters are evaluated on the base of the theoretical model presented in work [8], where nails function as linking of sheathing to framing dowels. In the presented model the stapling fasteners are adopted in the form of rounded dia. $5.7 \mathrm{~mm}$ in the cross-section beam element. The $12 \mathrm{~mm}$ length of fastener has been used on the basis of the study mode of failure shown on Figure $3 c$. 
a)

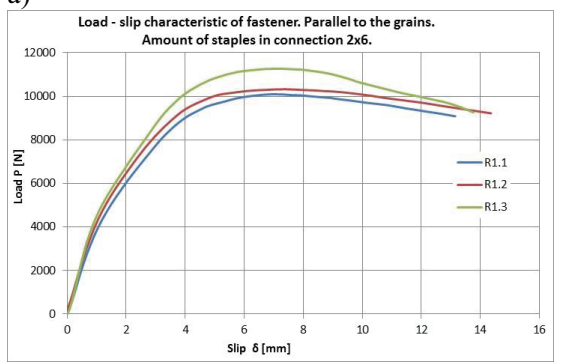

b)

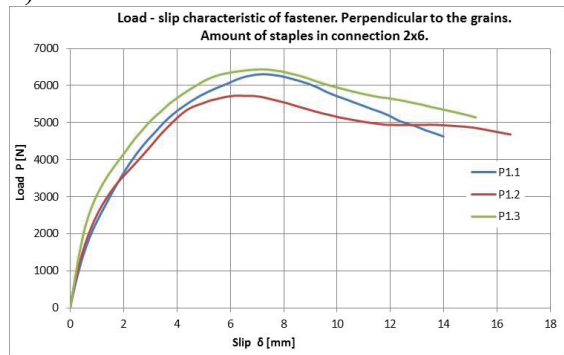

Fig. 4. Experimental test results of load-slip characteristics for staples fasteners:

a) load parallel to the grains, b) load perpendicular to the grains

Modulus of deformability $K_{s e r}=600.81 \frac{\mathrm{N}}{\mathrm{mm}}$ and deformation in the form of slip in joint $\delta=0.4 \mathrm{~mm}$ corresponds to load to dowel equal $P=240.324 N$. Accepting determined in this way formula $\mathrm{P} / \delta$ parameters: $\mathrm{E}=2500 \mathrm{MPa}, \mathrm{G}=960 \mathrm{MPa}$ and $v=0.3$ were assigned based on canonical relations of the displacement method for both sides of the fixed beam. Parameters in the direction parallel/perpendicular to grain were separately determined accepting adequate joint deformability, according to tests.

\subsubsection{MATERIAL PARAMETERS EVALUATION FOR STAPLED CONNECTION REGARDED THE SHELL FINITE ELEMENT}

The transformation of beam fasteners into shell elements of constant thickness required assigning a value set in a matrix (1.1), element thickness and display reaction correctness to deformations in plate and plane state. Isotropic material parameters assigned above were accepted and then fit controlling concordance of loading with displacements determined in the form of modulus deformability $\mathrm{K}_{\text {ser. }}$ An identification process has been conducted in FE-analysis tasks for schemes shown in Figure 5. This process assumed determination of element thickness in flexure state (Figure 5a) and shear modulus $\mathrm{G}_{12}$ in the plate state (Figure 5b). A material coordinates system has been taken with accordance to Figure 6. 
a)

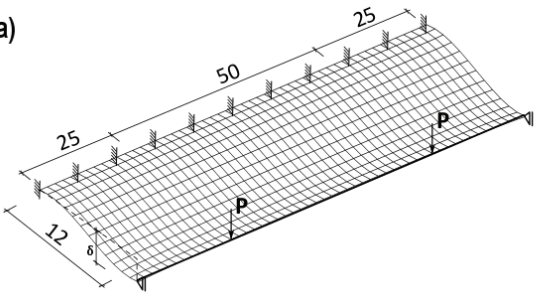

b)

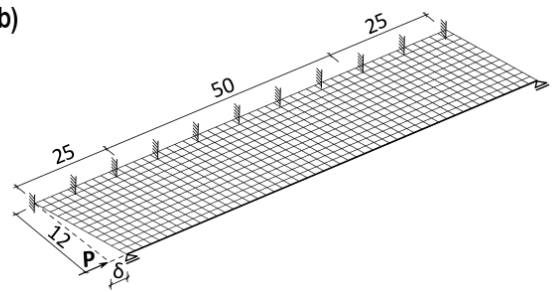

Fig.5. Analytical model of joint with shell fastening elements: a) perpendicular to grain, b) parallel to grain

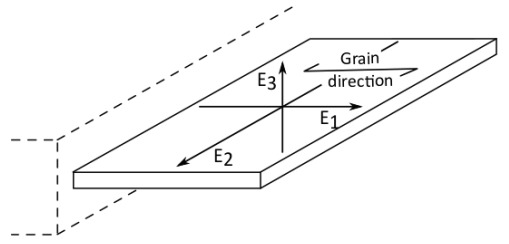

Fig. 6. Coordinates system of material for shell element adopted in model of joint

Established parameters are set in Table 2.

Table 2. Material parameters assessed for shell elements describing stapled connection

\begin{tabular}{|c|c|c|c|c|c|c|}
\hline \multicolumn{6}{|c|}{ Parameter established in the FEM analysis } & \multirow{2}{*}{$\begin{array}{c}\text { Thickness of } \\
\text { shell elements } \\
\text { h [mm] }\end{array}$} \\
\hline $\begin{array}{c}\text { Modulus of } \\
\text { elasticity } \\
\mathrm{E}_{1}[\mathrm{MPa}]\end{array}$ & $\begin{array}{c}\text { Modulus of } \\
\text { elasticity } \\
\mathrm{E}_{2}[\mathrm{MPa}]\end{array}$ & $\begin{array}{c}\text { Stiffness } \\
\text { modulus } \\
\mathrm{G}_{12}[\mathrm{MPa}]\end{array}$ & $\begin{array}{c}\text { Stiffness } \\
\text { modulus } \\
\mathrm{G}_{1 \mathrm{Z}}[\mathrm{MPa}]\end{array}$ & $\begin{array}{c}\text { Stiffness } \\
\text { modulus } \\
\mathrm{G}_{2 \mathrm{Z}}[\mathrm{MPa}]\end{array}$ & $\begin{array}{c}v \\
\text { ratio }\end{array}$ & \\
\hline 2500 & 2500 & 72 & 960 & 960 & 0,3 & 2.03 \\
\hline
\end{tabular}

\section{VERIFICATION OF PRESENTED ANALYTICAL METHOD}

A wall without openings measuring $2 \times 1.20 \times 2.50 \mathrm{~m}$ constructed of wood-frame, with both sides OSB 3 sheathing technology, has been analyzed. OSB sheathing was divided along the middle timber post of the wall, where both boards of sheathing were linked with two parallel rows of stapling fasteners. A concentrated load $\mathrm{P}=2.00 \mathrm{kN}$ was applied to the upper corner of wall causing bending of the diaphragm out of its plane (Figure 7a). The obtained results were compared to the experimental test results conducted on similar wall panels in the laboratory of the Chair of Structure Mechanics Bialystok University of Technology (Figure 7b). Displacements $\delta$ of wall out of plane at the height and 
in the direction of P loading action were analyzed, and axial stress in the 1-1 cross-section of mostly stressed post as well as in the sheathing in the 2-2 cross-section of wall (half height of wall) were determined.
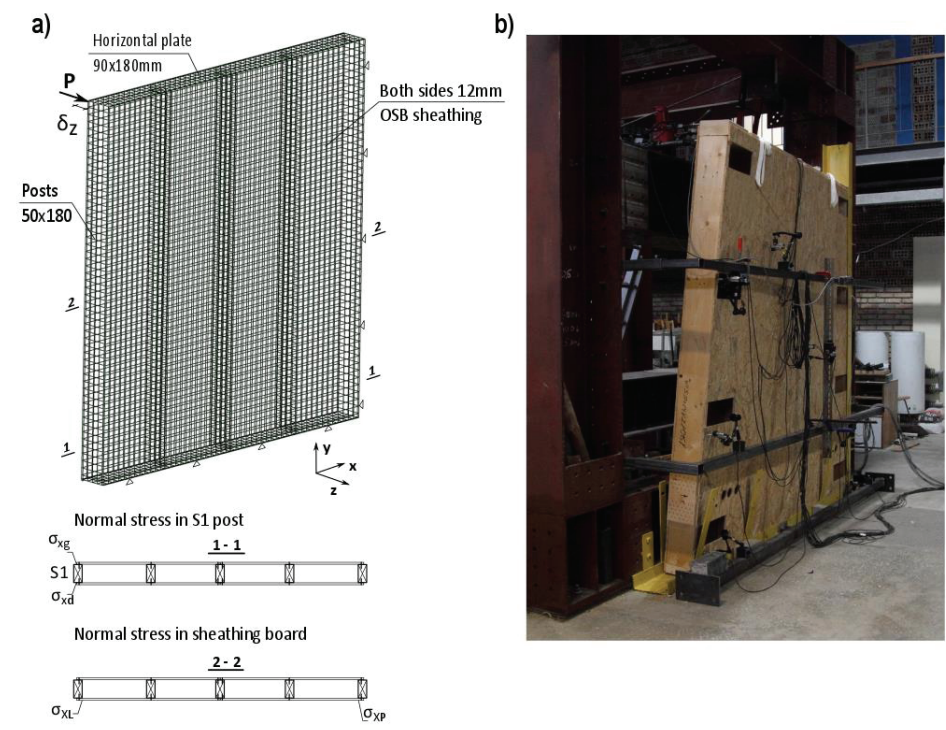

Fig.7. Wood-framed wall used in experimental test and analyses: a) discretization mesh and loading, b) view of experimentally tested panel

Analysis was conducted in four stages, through the kind and size of applied finite elements: small shell elements $5 \times 5 \mathrm{~cm}$, medium shell elements $10 \times 10 \mathrm{~cm}$, large shell elements $20 \times 20 \mathrm{~cm}$, mixed in size shell elements with their condensation along the edges and in the corners.

Table 3. Results of displacements and stressing from FE-analysis applying varying finite elements in joint modeling

\begin{tabular}{|c|c|c|c|c|c|c|c|}
\hline \multirow{3}{*}{$\begin{array}{l}\text { Kind of linking } \\
\text { elements }\end{array}$} & \multirow{3}{*}{$\begin{array}{c}\text { Number of } \\
\text { unknown }\end{array}$} & \multirow{3}{*}{$\begin{array}{c}\text { Displacem } \\
\text { ents } \\
\delta_{z}[\mathrm{~mm}]\end{array}$} & \multicolumn{4}{|c|}{ Normal stress in cross-section } & \multirow{3}{*}{$\begin{array}{l}\text { Degree of } \\
\text { unknown in } \\
\text { task }\end{array}$} \\
\hline & & & \multicolumn{2}{|c|}{ Post S1 } & \multicolumn{2}{|c|}{ Sheathing board } & \\
\hline & & & $\sigma_{\mathrm{xg}}[\mathrm{kPa}]$ & $\sigma_{\text {xd }}[\mathrm{kPa}]$ & $\sigma_{\mathrm{xL}}[\mathrm{kPa}]$ & $\sigma_{\mathrm{xP}}[\mathrm{kPa}]$ & \\
\hline beam links & 44769 & 39,13 & -471 & 261 & -14 & -395 & $100 \%$ \\
\hline small size of shell & 44792 & 33,27 & -562 & 304 & -33 & -341 & $100 \%$ \\
\hline medium size of shell & 13295 & 33,05 & -762 & 510 & -10 & -321 & $30 \%$ \\
\hline large size of shell & 4121 & 32,45 & -770 & 529 & -31 & -309 & $9 \%$ \\
\hline mixed in size shell & 5588 & 34,96 & -699 & 522 & -39 & -311 & $12 \%$ \\
\hline experimental test & -- & 36,21 & -599 & 431 & -- & -- & -- \\
\hline
\end{tabular}


Linking elements were taken in the form of beam elements with dimensions $\mathrm{L}=12 \mathrm{~mm}, \mathrm{~d}=5.7 \mathrm{~mm}$ and in the form of shell elements with dimensions of: $\mathrm{L}=12 \mathrm{~mm}, \mathrm{~b}=50 \mathrm{~mm}$ (or less), $\mathrm{h}=2.03 \mathrm{~mm}$.

In the first stage shell elements of sheathing and framing were linked with beam elements. In the successive stages instead of beam linking elements the shell. Results obtained in analyses are set in Table 3, Figure 8, and Figure 9.

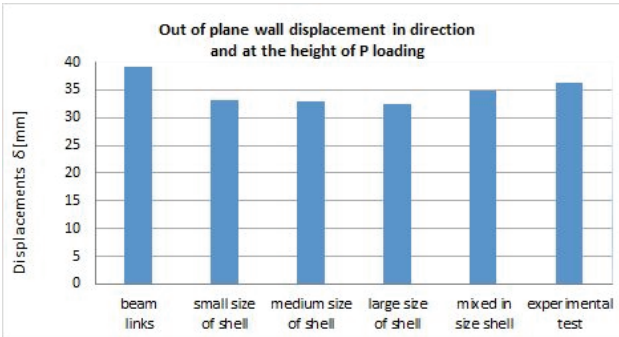

Fig. 8. Displacements $\delta$ out of the wall plane in the direction of loading P perpendicularly acting to the diaphragm
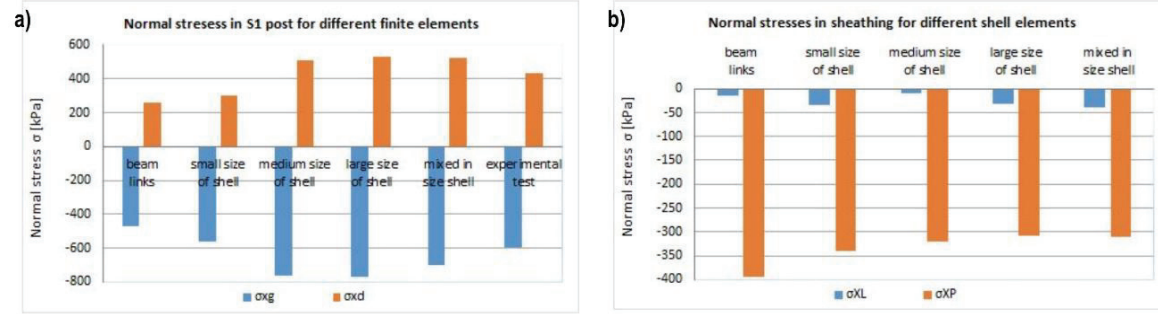

Fig.9. Normal stresses: a) along the grain direction in the cross-section of S1 post, b) parallel to the direction of OSB3 sheathing board, in the cross-section at the mid-height of wall diaphragm

\section{Conclusions}

Initial analytical beam models of fasteners linking sheathing to framing are based on the large number of finite elements, implicating adequately large number of unknowns. That analysis procedure allows us to solve problems of selected parts of buildings, like single walls, floors, or roof panels. Analysis of whole building structures with details of inter-elements connections creates a hard-to-resolve task. 
It seems that the aim to evaluate analytical models in a lesser degree of complication in evaluation, being reduced not only to the plane elements devoid of three-dimensional form attributes (plate state or shell state); has been realized. The solved problem can be counted on to be precise, giving the pattern of stressing in all elements comprising the structure, and at the same time correctly imitating structural displacements.

A significant simplification on the stage of modeling three-dimensional (3D) structures and a considerable reduction in the number of unknowns is acquired when applying proposed model. An application of medium shell elements decreases the number of unknowns by $70 \%$. Successively conducted analyses has proven that a better reflection of real structure behavior has been obtained applying a model of mixed-in-size finite shell elements, in addition to reducing by $80 \%$ the number of unknowns. The proposed solution can be successfully used in displacements and stressing analyses of three-dimensional wood-framed structures with sheathing for whole building or modular structures. In the author's opinion, the proposed model significantly simplifies the process of analysis, reflecting behaviors and responses of the structure under loading. Further analyses are being conducted, and they are essential for multistory and multifamily dwellings, where the process of modeling is particularly time-consuming.

\section{REFERENCES}

1. Falk R.H., Itani R.Y.: Finite Element Modeling of Wood Diaphragms. Journal of Structural Engineering No 3. March 1989.

2. Kasal B., Leichiti R.J.: Nonlinear Finite - Element Model for Light Frame Stud Walls. Journal of Structural Engineering, No.11. November 1992.

3. Kasal B., Leichiti R.J., Itani R.Y.: NonlinearFinite - Element Model of Complete Light - Frame Wood Structures. Journal of Structural Engineering, Vol.120, No.12. December 1994.

4. Kasal B., Leichiti R.J.: Nonlinear Finite - Element Model for Light Frame Stud Walls. Journal of Structural Engineering, No.11. November 1992.

5. Itani R. Y., Cheung C. K.: Nonlinear Analysis of Sheathed Wood Diaphragms. Journal of Structural Engineering, No. 9. September 1984

6. Schmidt R.J., Moody R.C.: Modeling LaterallyLoadedLight - FrameBuildings. Journal of Structural Engineering, Vol.115, No.1. January 1989.

7. Tarabia A.M., Itani R.Y.: Static and Dynamic Modeling of LightFrame Wood Buildings. Computer And Structures Vol. 63, No. 2/1997.

8. Malesza M.: Redystribution of internal forces and deformation of wood-framed with sheathing wall diaphragms. Doctor thesis. Bialystok University of Technology. Bialystok 1997. (in Polish). 


\section{LIST OF FIGURES AND TABLES:}

Fig. 1. Theoretical models used in analysis: a) proposed new model with application of shell elements with condensed discretization mesh at the edges and in the corners, b) former model with beam finite elements linking sheathing to framing of uniform spacing

Rys. 1. Teoretyczne modele obliczeniowe stosowane w analizie: a) proponowany model z zastosowaniem elementów powłokowych z zagęszczeniem siatki na krawędziach i w narożach, b) model bazowy z łącznikami belkowymi o stałym rozstawie,

Fig. 2. Coordinates system of material axes in elements: a) timber framing, b) sheathing boards

Rys. 2. Układ osi materiałowych w elementach: a) szkieletu drewnianego, b) płyty poszycia

Fig. 3. a) Staples arrangement in joint, b) geometry of two arms of staple, c) fastener mode of failure

Rys. 3. a) Układ zszywek w złączu, b) geometria układu ramion zszywek, c) deformacja łącznika

Fig. 4. Analytical model of joint with shell fastening elements: a) perpendicular to grain, b) parallel to grain

Rys. 4. Schemat obliczeniowy złącza na łączniki powłokowe dla obciążenia: a) prostopadłego do kierunku włókien, b) równoległego do kierunku włókien

Fig. 5. Coordinates system of material for shell element adopted in model of joint

Rys. 5. Osie materiałowe elementu powłokowego zastosowanego w modelu złącza

Fig. 6. Wood-framed wall used in experimental test and analyses: a) discretization mesh and loading, b) view of experimentally tested panel

Rys. 6. Ściana szkieletowa przyjęta w analizie: a) schemat obciążenia, b) widok badanej tarczy

Fig. 7. Displacements $\delta$ out of the wall plane in the direction of loading P perpendicularly acting to the diaphragm

Rys. 7. Przemieszczenia $\delta \mathrm{w}$ płaszczyźnie ściany na kierunku obciążenia $P$

Fig.8. Normal stresses: a) along the grain direction in the cross-section of S1 post, b) parallel to the direction of OSB3 sheathing board, in the cross-section at the mid-height of wall diaphragm

Rys. 8 Naprężenia normalne: a) równoległe do kierunku włókien w przekroju słupka S1, b) równoległe do kierunku ułożenia płyty OSB w połowie wysokości ściany

Table 1. Material strength characteristics of spruce wood and OSB sheathing boards.

Tabela 1. Parametry wytrzymałościowe drewna i płyty OSB

Table 2. Material parameters assessed for shell elements describing stapled connection

Tabela 2. Parametry materiałowe ustalone dla elementów powłokowych w złączu

Table 3. Results of displacements and stressing from FE-analysis applying varying finite elements in joint modeling

Tabela. 3. Wyniki odkształceń i naprężeń uzyskane w analizach MES przy zastosowaniu różnych elementów skończonych w złączu 


\section{EFEKTYWNY MODEL ANALIZY SZKIELETOWYCH KONSTRUKCJI DREWNIANYCH}

Slowa kluczowe: szkieletowe budynki drewniane, analiza numeryczna, materiał ortotropowy,

\section{STRESZCZENIE:}

W artykule przedstawiono nowy sposób modelowania szkieletowych konstrukcji drewnianych w oparciu o metodę elementów skończonych. Głównym zagadnieniem są łączniki szkieletu drewnianego z płytą poszycia, w opisie których przyjmuje się elementy powłokowe o szczególnych cechach materiałowych. Parametry materiałowe ustala się na podstawie prób materiałowych oraz identyfikacji numerycznej. Celem autora jest opracowanie modelu numerycznego o dużej dokładności odwzorowania przy jednoczesnym zmniejszeniu liczby niewiadomych i uproszczeniu procesu modelowania konstrukcji. W konsekwencji nowa metoda może ułatwić analizy budynków wielorodzinnych.

Proponuje się model przestrzenny (3D), który z jednej strony uwzględnia wszystkie elementy składowe panelowych konstrukcji szkieletowych, a z drugiej zmniejsza liczbę niewiadomych (w konsekwencji wielkość zadań obliczeniowych). Wprowadza się nowy opis łączników poszycia ze szkieletem drewnianym za pomocą elementów powłokowych. Główną intencją jest zastosowanie modelu do rozwiązywania dużych zadań przez redukcję niewiadomych i skrócenie czasu modelowania konstrukcji w programach MES. Cel może być osiągnięty poprzez zastosowanie w opisie konstrukcji jedynie powłokowych elementów skończonych o stosunkowo dużych wymiarach zagęszczonych na krawędziach i w narożach.

Taki model pozwala grupować łączniki w jeden większy element oraz zagęszczać siatkę dyskretyzacyjną w rejonach gdzie występują największe wytężenia i koncentracja naprężeń. Łączniki opisuje się elementami powłokowymi podobnie jak rygle, słupki oraz płytę poszycia. Do realizacji zadania wymagane jest ustalenie odpowiednich parametrów geometrycznych i materiałowych, które w przypadku łączników są wynikiem współpracy trzech ośrodków: metalowej zszywki, drewnianego szkieletu konstrukcji oraz drewnopochodnej płyty poszycia. W proponowanym modelu przyjmuje się, iż wszystkie zastosowane materiały wykazują cechy ortotropowe ustalone na podstawie badań doświadczalnych.

Parametry drewna oraz płyty OSB są znane i możliwe do bezpośredniej aplikacji. Analizę obliczeniową łączników podzielono na dwa etapy. W pierwszym ustalono parametry zszywek opisanych w analizie za pomocą izotropowych elementów belkowych rozstawionych co $50 \mathrm{~mm}$. W drugim ustalono parametry zszywek przyjętych do analizy w postaci elementów powłokowych o charakterze ortotropowym.

Parametry materiałowe złączy nie mogą być odczytane bezpośrednio z badań doświadczalnych. W wyniku eksperymentu uzyskuje się informacje o podatności złącza tzn relację pomiędzy obciążeniem, a przemieszczeniem łącznika, . Podatność jest wynikiem wzajemnego oddziaływania materiału zszywki oraz otoczenia, w którym jest ona zagłębiona. Ustalenia modułów E, G oraz v dokonano w procesie identyfikacji numerycznej dla założonej podatności.

Podobnie poprzez identyfikację numeryczną ustalono parametry łączników w postaci elementów powłokowych o określonej grubości wykazując poprawność reakcji na odkształcenia w stanie płytowym i tarczowym.

Weryfikację proponowanego rozwiązania przeprowadzono na przykładach obliczeniowych tarczy ściennej poddanej zginaniu z płaszczyzny, obciążonej punktowo w jednym z naroży. Obliczenia wykonano przy zastosowaniu łączników 
w postaci elementów belkowych oraz powłokowych o różnej wielkości (gęstości siatki). Wyniki porównano z rezultatami badań doświadczalnych ścian o podobnej konstrukcji.

Można przyjąć, iż dążenie do opracowania modelu, który będzie mniej skomplikowany w budowie, ale też nie sprowadzony jedynie do płaskich tarcz pozbawionych cech przestrzenności (stan płytowy, czy powłokowy) zostało zrealizowane. Zastosowane rozwiązanie należy zaliczyć do dokładnych dających obraz wytężenia wszystkich elementów konstrukcji oraz poprawnie odwzorowujących jej odkształcenia. Jednocześnie uzyskano olbrzymie ułatwienie na etapie modelowania przestrzennego konstrukcji oraz znaczne ograniczenia w ilości niewiadomych. Zastosowanie elementów powłokowych o średniej wielkości zmniejszyło ilość niewiadomych o 70\%. Kolejne analizy wykazały, iż lepsze odzwierciedlenie rzeczywistych reakcji konstrukcji uzyskano w modelu o mieszanych wielkościach elementów skończonych redukując jednocześnie ilość niewiadomych o około $80 \%$.

Zaproponowane rozwiązanie może być z powodzeniem wykorzystane w analizach szkieletowych konstrukcji drewnianych ze współpracującym poszyciem. Zdaniem autora ułatwiają one w znacznym stopniu proces obliczeniowy zachowując pełny obraz odpowiedzi konstrukcji na obciążenia. W dalszym ciągu niezbędne są kolejne analizy, szczególnie dla całych budynków wielorodzinnych, gdzie proces budowania modelu jest szczególnie pracochłonny i czasochłonny. 